\title{
Book Review: Manual of Fracture Management-Foot and Ankle [AO Trauma: Rammelt S, Swords M, Dhillon MS, Sands A: Thieme Publishers (Jan 2020)]
}

\author{
Himanshu Bhayana ${ }^{1}$, Pratik M Rathod ${ }^{2}$ \\ Keywords: Ankle, Bones, Foot, Fracture fixation, Trauma and orthopedics, Trauma surgery. \\ Journal of Postgraduate Medicine, Education and Research (2020): 10.5005/jp-journals-10028-1419
}

Although there are oceans of texts available in the world, yet this invaluable textbook is special and unique as it is written by four of the world's leading authorities on management of foot and ankle surgery who have themselves overcome many challenges in this field and have a very long-standing experience. This book furnishes a crystal-clear guide and easy-to-understand concepts that can be well understood by a beginner and an expert alike. The book contains 6 subdivisions and 45 chapters each giving an insight on the anatomy, biomechanics, and treatment protocol of the management of injury over various aspects of the foot and ankle region.

More than 1,500 illustrations and radiological imaging along with 59 detailed cases covering the myriad of foot and ankle injuries constitute one of the impeccable highlights of this publication. Another key feature is the refreshing approach of imparting information by covering the wide range of bony and soft tissue injuries around the region and providing detailed emphasis on decision making, preoperative planning, surgical approaches, alternative techniques, and postoperative rehabilitation.

It makes a simple read for the surgeons who wish to go through or brush up just before entering the operation theater/room as well as for those who wish to read the text for building long-term
1,2Department of Orthopaedics, Postgraduate Institute of Medical Education and Research, Chandigarh, India

Corresponding Author: Pratik M Rathod, Department of Orthopaedics, Postgraduate Institute of Medical Education and Research, Chandigarh, India, Phone: +91 9480100456, e-mail: pratik3800@gmail.com

How to cite this article: Bhayana $H$, Rathod PM. Manual of Fracture Management-Foot and Ankle [AO Trauma: Rammelt S, Swords M, Dhillon MS, Sands A: Thieme Publishers (Jan 2020)]. J Postgrad Med Edu Res 2020;54(4):252.

Source of support: Nil

Conflict of interest: None

conceptual foundations. It has the simplest of language, which directly connects the authors' thought to the readers' mind. The diligent hard work of the editors in collating and organizing the clinical material is discernable and would be welcomed by various emerging and established foot and ankle surgeons around the world. This book is an end of the search for anyone looking for a complete and exhaustible information of the foot and ankle trauma and surgery.

(c) The Author(s). 2020 Open Access This article is distributed under the terms of the Creative Commons Attribution 4.0 International License (https://creativecommons. org/licenses/by-nc/4.0/), which permits unrestricted use, distribution, and non-commercial reproduction in any medium, provided you give appropriate credit to the original author(s) and the source, provide a link to the Creative Commons license, and indicate if changes were made. The Creative Commons Public Domain Dedication waiver (http://creativecommons.org/publicdomain/zero/1.0/) applies to the data made available in this article, unless otherwise stated. 